\title{
Proximate Composition of Cowpea (Vignaunguiculata (L.) Walp) Grains Preserved with Mixtures of Neem(Azadirachtaindica A.Juss) and Moringa(Moringaoleifera)Seed Oils
}

\author{
${ }^{1}$ Ilesanmi, J.O.Y and ${ }^{2}$ Gungula, D.T. \\ ${ }^{1}$ Department of Food Science and Technology.Modibbo Adama University of Technology, Yola. \\ ${ }^{2}$ Department of Crop Production and Horticulture, Modibbo Adama University of Technology, Yola. \\ Corresponding author Email: dgungula@mautech.edu.ng; +2348035742004
}

\begin{abstract}
The use of bioinsecticides for the control of storage insect pests by small scale farmers is anchored on their availability, affordability, safety, quality and effectiveness. Although neem-moringa seed oils mixtures have satisfactorily preserved cowpea grains up to 270 days, the proximate composition of the treated grains is not documented. This research was carried out to determine the proximate composition of cowpea grains treated with mixtures of neem-moringa oils and stored for 270 days. The mixtures of theoils at ratio 1: 3 and 1:2 neem:moringa were applied on cowpea at concentrations of 2.5 $\mu \mathrm{l} / \mathrm{g}$ and $5.0 \mu \mathrm{l} / \mathrm{g}$ of cowpea grains,proximate composition data were collected at the end of every 90 day sand analysed statistically. The results showed that treatment of cowpea grains with ratio 1:3/2.5 and $5.0 \mu \mathrm{l} / \mathrm{g}$ mixture of neem-moringa seed oils had no significant $(P<0.05)$ effect on the proximate composition of cowpea even at 270 days of storage unlike other treatments. The study concludes that mixture of neem-moringa seed oils at 1:3/5.0 $\mathrm{\mu l} /$ ggave the best performance in terms of its effectson the proximate composition of the stored cowpea grains as such it is recommended for preservation of cowpea grains for maximum nutritional benefits.
\end{abstract}

Keywords: Proximate composition,Moringa, Neem,Seed oils, Cowpea.

\section{INTRODUCTION}

Cowpea (Vignaunguiculata (L.)Walp) is an important tropical legume crop of African origin and has become an integral part of the tropical cropping system, particularly in the semi-arid West Africa Savannah (Asante et al., 2000). It is a heat - loving, drought tolerant crop with a low soil fertility requirement (Karunasena, 2001). Africa alone accounts for 7.5 million hectares of the estimated world total area of about 10 million hectares and about $70 \%$ of which lies in West and Central Africa (Singh et al., 1996). The crop is considered the second most important food grain legume and constitutes a cheap source of protein for humans. Cowpea grain is nutritious and inexpensive. It contains about $25 \%$ protein and $64 \%$ carbohydrate (Kormawa, 2000). It is also use as livestock feed. The haulm is high - value nutritious forage (ABIOTECH, 2002). Cowpea is the second most important source of protein, next to meat in Nigeria (Olapade et al., 2003). It is cooked plain, mixed with other foods and processed into formulated recipes such as "moimoi", a steamed paste, or "akara", a deep fat fried paste product. Its regular consumption increases the need and importance of a proper storage system. Compared to many other crops grown in semi - arid tropics, the cowpea post - production system (storage and processing) in developing countries is associated with many constraints. In particular, weevils (postharvest pests) can destroy a granary full of cowpea within two or three months (ABIOTECH, 2002). This is seen as a serious challenge to postharvest and storage technology discipline. Infestation by insects can also affect the food processing and nutritional qualities of cowpea (ABIOTECH, 2002).

Mature dry cowpea is important in the diet of many population groups around the world (Singh et al., 1995). This food legume is readily available, in expensive and a popular part of traditional food system. Cowpeas along 
Table 1. Proximate Composition of Cowpea Grains Treated with Neem and MoringaSeed Oils Mixture

\begin{tabular}{llllllr}
\hline Treatment & Moisture & Ash & Fat & Fibre & Protein & Carbohydrate \\
\hline Control & 14.60 & 3.36 & 3.13 & 2.11 & 19.71 & 57.17 \\
$1: 2 / 2.5 \mu \mathrm{l} / \mathrm{g}$ & 10.69 & 4.89 & 3.88 & 2.39 & $27.10 ?$ & 51.60 \\
$1: 2 / 5.0 \mu \mathrm{l} / \mathrm{g}$ & 11.71 & 4.12 & 3.44 & 1.50 & 22.00 & 57.23 \\
$1: 3 / 2.5 \mu \mathrm{l} / \mathrm{g}$ & 10.22 & 3.51 & 3.33 & 1.61 & 19.37 & 61.73 \\
$1: 3 / 5.0 \mu \mathrm{l} / \mathrm{g}$ & 11.33 & 3.43 & 3.50 & 1.67 & 19.70 & 60.53 \\
Mean & 11.71 & 3.86 & 3.46 & 1.86 & 21.58 & 57.65 \\
LSD at 0.05 & 0.58 & 0.16 & 1.11 & 0.77 & 0.78 & 1.60 \\
Prob. of $\mathrm{F}$ & $<0.001$ & $<0.001$ & 0.732 & 0.116 & $<0.001$ & $<0.001$ \\
\hline
\end{tabular}

with other legumes are recognized as important sources of proteins (Agazounon et al., 2004). The grain and leaves are sources of carbohydrates, proteins, fats, $\beta-$ carotene, and vitamins $B$ and $C$ which are necessary for maintaining good health (Enwere et al., 1998). The other vegetative part of the cowpea plants after removal of the grain, are used as feed forage, hay and silage for livestock (Mamiro et al., 2011). Petty trading of fresh produce and processed foods provide both rural and urban opportunities for earning cash, particularly by women (Singh et al., 1997). Cowpea (Vignaunguiculata L. Walp) provides more than half the plant protein in human diet. It is agood source of calories, vitamins and minerals and provides a significant amount of dietary lysine which is limiting in cereals. In regions of chronic protein shortage, it provides food or fairly high nutritive value to both humans and domestic animals. The objective of this research wasto assess the nutritional compositionof cowpea grains treated with ratio $1: 2$ and $1: 3$ neem-moringa seed oils at concentration of $2.5 \mu \mathrm{l} / \mathrm{g}$ and $5.0 \mu \mathrm{l} / \mathrm{g}$ of cowpea grains within the storage period that lasted for 270 days.

\section{MATERIALS AND METHODS}

The neem seeds (Azadirachterindica $A$. Juss) used in this study were handpicked from the premises of Modibbo Adama University of Technology Yola. The moringa (Moringaoleifera) seeds were also obtained partly from ModibboAdama University of Technology Yola premises of Adamawa state Nigeria and Kaltungo Local Government Area of Gombe state Nigeria. The cowpea samples (Ife brown) used was obtained from a farm within Modibbo Adama University of Technology Yola and the plastic bowls for storage were purchased from Jimeta marketYola in Adamawa state, Nigeria.

The neem and moringa seeds oils were traditionally extracted and cowpea grains was treated for storage with the mixture of these oils in ratios of $1: 2$ and $1: 3$ at a concentration of $2.5 \mu \mathrm{l} / \mathrm{g}$ and $5.0 \mu \mathrm{l} / \mathrm{g}$ of cowpea grains. The treated cowpea grains were kept at ambient temperature $\left(37^{\circ} \mathrm{C}\right)$ for 270 days. At the end of every 90 days of storage, data were collected on the proximate composition of the treated and untreated (control) cowpea grain samples.
Crude protein was determined according to the method of AOAC (2006), crude fat, moisture, total ash and crude fibre of the treated and untreated cowpea were determined using the method of AOAC (2006). Determination of carbohydrates was calculated by difference. (Egan et al., 1981)

\section{RESULTS}

Effect of mixtures of neem-moringa seed oils on proximate composition of stored cowpea grains

The results of proximate analysis (moisture, total ash, crude fat, crude fibre, crude protein and carbohydrate) of cowpea grains treated with two levels of ratios $1: 2$ and $1: 3$ mixture of neem and moringa seed oils presented on Table 1 showed that the moisture content ranged from $10.22-14.60 \%$. The control sample had the highest moisture content of $14.60 \%$ while cowpea grains treated with ratio $1: 3 / 2.5 \mu \mathrm{l} / \mathrm{g}$ had the least $(10.22 \%)$ moisture at the end of 270 days of storage. There were no significant difference $(p<0.05)$ between the moisture content of samples treated with the same level of the oils i.e. ratios $1: 2 / 2.5 \mu \mathrm{l} / \mathrm{g}$ and $1: 3 / 2.5 \mu \mathrm{l} / \mathrm{g}$ and also no significant difference $(p<0.05)$ between those treated with ratio $1: 2 /$ $5.0 \mu \mathrm{l} / \mathrm{g}$ and $1: 3 / 5.0 \mu \mathrm{l} / \mathrm{g}$. There were however significant differences $(p<0.05)$ between the moisture content of the treated samples and the control (untreated cowpea grains).

The results of the total ash content is presented in Table 1.At the end of the storage periods, the total ash contentranged from $3.36-4.89 \%$. Cowpea grains treated with ratio $1: 2 / 2.5 \mu \mathrm{l} / \mathrm{g}$ neem and moringa seed oils has the highest $(4.89 \%)$ ash, while the control sample had the least $(3.36 \%)$ ash. There were no significant differences $(p<0.05)$ between the control samples and the samples treated with ratio 1:3 neem - moringa seed oils. There were however significant differences $(p<0.05)$ between the ash content of the untreated cowpea grains (control) compared to the ash content of the cowpea grains treated with 1:2 neem - moringa seed oils at the end of the storage period.

There was no significant difference $(p>0.05)$ in the crude fat content of the control samples and the treated samples (Table 1$)$. In the same vein, there were no 
120 Afr. J. Food Sci. Technol.

Table 2. Effect of Storage Period on the Proximate Composition of Cowpea Grains Treated with Mixtures of Neem and Moringa Seed Oils

\begin{tabular}{llllllc}
\hline Period (Days) & Moisture & Ash & Fat & Fibre & Protein & Carbohydrate \\
\hline 90 & 13.08 & 3.18 & 3.24 & 1.60 & 19.32 & 59.60 \\
180 & 9.57 & 4.04 & 3.37 & 1.17 & 20.96 & 61.34 \\
270 & 12.48 & 4.36 & 3.77 & 2.80 & 24.45 & 52.03 \\
Mean & 11.71 & 3.86 & 3.46 & 1.86 & 21.58 & 57.65 \\
LSD at 0.05 & 0.45 & 0.12 & 0.86 & 0.59 & 0.61 & 1.24 \\
Prob. of F & $<.001$ & $<.001$ & 0.438 & $<.001$ & $<.001$ & $<.001$ \\
\hline
\end{tabular}

significant differences $(p>0.05)$ in the fibre contents of the control samples and the treated cowpea grains samples.

The protein contents of both treated and untreated cowpea grains ranged from 19.37 to $27.10 \%$ (Table 1 ). The cowpea grains samples treated with ratio $1: 2$ neem moringa seed oils significantly $(p<0.05)$ increased in their protein content when compared with those treated with ratio 1:3 neem - moringa seed oils and the untreated cowpea grains. There were however no significant differences $(p<0.05)$ in the protein content of cowpea grains treated with ratio $1: 3$ neem - moringa seed oils and the control. Cowpea grains treated with $1: 2 / 2.5 \mu \mathrm{l} / \mathrm{g}$ had the highest $(27.10 \%)$ protein content while cowpea grains treated with ratio $1: 3 / 5.0 \mu \mathrm{l} / \mathrm{g}$ recorded the least (19.37\%) protein content.

The carbohydrate content ranged between 51.60 and $61.73 \%$ (Table 1$)$. The highest $(61.73 \%)$ being from cowpea treated with ratio $1: 3 / 2.5 \mu / \mathrm{g}$ followed by those treated with ratio $1: 3 / 5.0 \mu \mathrm{l} / \mathrm{g}$ neem - moringa seed oil with mean value of $60.73 \%$. There were significant differences $(p<0.05)$ among those treated with ratio $1: 3$ neem - moringa seed oils and those treated with ratio $1: 2$ neem - moringa seed oils. Also the carbohydrate content of cowpea samples treated with ratio $1: 2 / 2.5 \mu \mathrm{l} / \mathrm{g}$ significantly decreasedwhen compared with the control and other treated samples.

The effects of storage period on the proximate composition of cowpea treated with mixtures of neem and moringa seed oils

Table 2 contains the result of the effects of storage period on the proximate composition of cowpea treated with mixtures of neem and moringa seed oils. There were significant differences $(p<0.05)$ in the moisture and ash content overthe storage periods (90,180, and 270 days), while there were no significant difference $(p<0.05)$ in the fat and fibre contents of those samples stored for 90 days and 180 days but at the end of 270 days there was a significant increase in percentage fibre content. Furthermore, there were significant differences $(p<0.05)$ in the protein content of the samples for all the sampled periods. Finally there were no significant differences in the carbohydrates content of those samples stored for 90 days and 180 days, however there were significant reduction in the carbohydrate content of the samples at the end of 270 days.

\section{Interaction of storage and treatment with varying concentrations of mixtures of neem and moringa seed oils on the proximate composition of the stored cowpea grains}

The interactions between storage periods and treatment of the stored cowpea grains with various concentrations of mixture of neem and moringa seed oils on proximate composition of stored cowpea grains are presented on Table 3. While at 90 days ofstorage, there were no significant differences in moisture content of the cowpea grains treated with the various ratios and concentrations, at 180 days ofstorage, cowpea grains treated with ratio $1: 3 / 2.5 \mu \mathrm{l} / \mathrm{g}$ recorded the lowest moisture content $(6.47 \%)$ followed by the one treated with ratio $1: 2 / 2.5 \mu \mathrm{l} / \mathrm{g}$ with moisture content of $8.53 \%$ with the highest moisture content (14.20\%) was recorded from the control treatment. However, at 270 days of storage, cowpea grains treated with ratio 1:2/2.5 $\mu \mathrm{l} / \mathrm{g}$ recorded the lowest moisture content $(10.27 \%)$ followed by cowpea grains treated with ratios $1: 3 / 2.5 \mu \mathrm{l} / \mathrm{g}$ and $1: 2 / 2.5 \mu \mathrm{l} / \mathrm{g}$ and then cowpea treated with ratio $1: 2 / 5.0 \mu \mathrm{l} /$ grecorded the moisture content of $13.19 \%$. the highest moisture content was again from the control. Generally, the moisture content decreased at 180 days of storage and then increased at 270 days of storage except for the control where there was continuous increased in moisture content with days in storage.

The interactions between the storage period and the cowpea grains treated with various ratios and concentration of neem and moringa seed oils on ash content showed that at 90 days ofstorage cowpea grains treated with ratio 1:2/2.5 $\mu \mathrm{l} / \mathrm{g}$ and $1: 3 / 5.0 \mu \mathrm{l} / \mathrm{g}$ recorded the highestash content $(3.21 \%)$ followed by the cowpea grains treated with ratio $1: 3 / 2.5 \mu \mathrm{l} / \mathrm{g}$ which recorded $3.20 \%$ ash content. The least ash content $(3.15 \%)$ was recorded from the cowpea grains treated with ratio $1: 2 / 2.5 \mu \mathrm{l} / \mathrm{g}$ and the control treatment.

At 180 days of storage, cowpea grains treated with ratio 1:2/2.5 $\mu \mathrm{l} / \mathrm{g}$ neem and moringa seed oils had the highest percentage ash content of 5.40 followed by cowpea grains treated with ratio $1: 2 / 5.0 \mu \mathrm{l} / \mathrm{g}$ which had 
Table 3.Interaction between Storage Period andVarying Concentration of Mixture of Neem and Moringa Seed Oils on the Proximate Composition of Cowpea Grains

\begin{tabular}{|c|c|c|c|c|c|c|c|c|}
\hline \multirow{2}{*}{$\begin{array}{l}\text { Period } \\
\text { (Days) }\end{array}$} & \multirow[t]{2}{*}{ Control } & \multicolumn{4}{|c|}{ Neem : Moringa Seed Oil Ratios } & \multirow[t]{2}{*}{ Mean } & \multirow{2}{*}{$\begin{array}{l}\text { LSD } \\
0.05 \\
\end{array}$} & \multirow{2}{*}{$\begin{array}{l}\text { Prob. of } \\
\text { F }\end{array}$} \\
\hline & & $1: 2 / 2.5 \mu \mathrm{l} / \mathrm{g}$ & $1: 2 / 5.0 \mu \mathrm{l} / \mathrm{g}$ & $1: 3 / 2.5 \mu \mathrm{l} / \mathrm{g}$ & $1: 3 / 5.0 \mu \mathrm{l} / \mathrm{g}$ & & & \\
\hline 90 & 13.20 & 13.27 & 13.00 & 13.13 & 12.80 & & & \\
\hline 270 & $\begin{array}{l}16.40 \\
\text { Ash }\end{array}$ & 10.27 & 13.19 & 11.07 & 11.47 & 11.71 & 1.01 & $<.001$ \\
\hline 90 & 3.13 & 3.21 & 3.15 & 3.20 & 3.21 & & & \\
\hline 180 & 3.33 & 5.40 & 3.93 & 3.80 & 3.73 & & & \\
\hline 90 & 19.58 & 20.23 & 18.32 & 18.43 & 20.01 & & & \\
\hline 180 & 18.51 & 29.56 & 19.13 & 18.54 & 19.08 & & & \\
\hline \multirow[t]{2}{*}{270} & 21.03 & 31.52 & 28.55 & 21.15 & 20.00 & 21.58 & 1.35 & $<.001$ \\
\hline & \multicolumn{5}{|c|}{ Carbohydrate } & & & \\
\hline 90 & 59.25 & 57.83 & 61.36 & 60.42 & 59.14 & & & \\
\hline 180 & 59.29 & 52.84 & 63.67 & 67.03 & 63.86 & & & \\
\hline
\end{tabular}

3.93. The least percentage ash content (3.73) during this period of storage was recorded from cowpea grains treated with ratio $1: 3 / 5.0 \mu \mathrm{l} / \mathrm{g}$ neem-moringa seed oils. At 270 days ofstorage, cowpea grains treated with ratio $1: 2 / 2.5 \mu \mathrm{l} / \mathrm{g}$ neem - moringa seed oil recorded the highest ash content $(6.07 \%)$ followed by those of the ones treated with ratio $1: 2 / 5.0 \mu \mathrm{l} / \mathrm{g}$. The least ash content (3.33\%) was however recorded from the cowpea grains treated with ratio $1: 3 / 5.0 \mu \mathrm{l} / \mathrm{g}$ neem-moringa seed oils.

The interaction between the storage period and cowpea grain treated with ratio $1: 2$ and $1: 3$ neemmoringa oils at various concentrations on protein content of stored cowpea grains is presented on Table 3. At 90 days ofstorage, cowpea grain treated with ratio $1: 2 / 2.5$ $\mu \mathrm{l} / \mathrm{g}$ had the highest percentage protein content $(20.23 \%)$ followed by one treated with ratio 1:3/5.0 $\mu \mathrm{l} / \mathrm{g}$ with percentage protein content of $20.01 \%$. The least protein content was from cowpea grains treated with ratio 1:2/5.0 $\mu \mathrm{l} / \mathrm{g}$ neem-moringa oils. At 180 days of storage also, cowpea grains treated with ratio $1: 2 / 2.5 \mu \mathrm{l} / \mathrm{g}$ neemmoringa seed oils had the highest protein content $(29.56 \%)$ followed by the grains treated with ratio $1: 3 / 5.0$ $\mu \mathrm{l} / \mathrm{g}$ with percentage protein content of $19.08 \%$. The least protein content was from ratio $1: 3 / 2.5 \mu \mathrm{l} / \mathrm{g}$ treated cowpea grains. The same trend was observed at 270 days ofstorage.

At 90 days ofstorage, cowpea grains treated with ratio $1: 2 / 5.0 \mu \mathrm{l} / \mathrm{g}$ neem - moringa oils had the highest amountof carbohydrate content $(61.36 \%)$ followed by the cowpea grains treated with ratio $1: 3 / 2.5 \mu \mathrm{l} / \mathrm{g}$ which had $60.42 \%$ and the least carbohydrate content $(57.83 \%)$ was recorded from the cowpea grains treated with ratio $1: 2 / 2.5 \mu \mathrm{l} / \mathrm{g}$ neem - moringa seed oils. The interaction of storage and treatment with neem - moringa seed oils ratio $1: 3 / 2.5 \mu \mathrm{l} / \mathrm{g}$ at 180 days of storage had the highest carbohydrate content (67.03\%) followed by cowpea grains treated with ratio $1: 3 / 5.0 \mu \mathrm{l} / \mathrm{g}$ neem - moringa oils that recorded $63.83 \%$ carbohydrate. While the least carbohydrate content $(52.84 \%)$ was from cowpea grains treated with ratio $1: 2 / 2.5 \mu \mathrm{l} / \mathrm{g}$ neem - moringa oils. Cowpea grains stored for 270 days and treated with ratio $1: 3 / 5.0 \mu \mathrm{l} / \mathrm{g}$ neem - moringa oils recorded the highest carbohydrate content $(58.60 \%)$ followed by those treated with ratio $1: 3 / 2.5 \mu \mathrm{l} / \mathrm{g}$ while cowpea treated with ratio $1: 2 / 2.5 \mu \mathrm{l} / \mathrm{g}$ had the least carbohydrate content $(44.15 \%)$.

\section{DISCUSSION}

The significantly $(p<0.05)$ lowest loss of moisture content from cowpea sample treated with ratio $1: 3 / 2.5 \mu \mathrm{l} / \mathrm{g}$ neem - moringa seed oilscould be due to the removal of water with absorption of oils into the seeds. This is evidenced from the highest moisture content $(14.60 \%)$ recorded in the control samples than all the treated samples. This result is consistent with the report of Gayan et al. (2006) who observed the effect of selected essential oils on physicochemical changes of stored cowpeatreated to control cowpea bruchids, Callosobruchusmaculatus. The result may also be due to absorption of moisture from the atmosphere by increased insect population and increased insect metabolism since the control samples were more susceptible to bruchid infestation than the rest samples.

The increase in the total fat content during the storage period of the cowpea grains treated with mixtures of neem and moringa seed oils might be due to the absorption of treated mixture of neem and moringa seed oils into the cowpea grains in minute quantities, which is evidenced by the characteristic odour present in these samples. This result is also comparable with the work of Gyan et al. (2006).

The no significant variation in the protein content in the control sample and the sample treated with ratio 
122 Afr. J. Food Sci. Technol.

$1: 3 / 2.5 \mu \mathrm{l} / \mathrm{g}$ and $1: 3 / 5.0 \mu \mathrm{l} / \mathrm{g}$ might be because while in the control samples, there were many insects and their eggs but the treated samples insects were effectively controlled. This result agrees with the result of Gayan et al. (2006). The significantly highest protein contents (27 and $22 \%$ ) of samples treated with ratio $1: 2 / 2.5$ and $1: 2 / 5.0 \mu \mathrm{l} / \mathrm{g}$ could be due to the many eggs and larva of C. maculatus on the cowpea grains due to infestation as that level of the oil could not preserve the cowpea grains samples longer than 180 days (llesanmi and Gungula, 2010). Similar observations were made by Danjumma et al. (2009) who found a progressive increase in the total nitrogen, total protein, non-protein and uric acid with increased level of infestation of wheat. The total protein content of the grains (as calculated from its nitrogen content was not affected during storage in untreated noninfested grains and in samples treated with ratio $1: 3 / 2.5$ $\mu \mathrm{l} / \mathrm{g}$ and $1: 3 / 5.0 \mu \mathrm{l} / \mathrm{g}$ neem - moringa seed oils. The increase in fibre content observed in the infested cowpea grains $(1: 2 / 2.5 \mu \mathrm{l} / \mathrm{g}$ treated) could be sue to the fact that for most endosperm, C. maculates hollowed out the content of the grains leaving only the seed coat which is largely made up of fibre. This is in agreement with the result of Danjumma et al. (2009) and Bamaiyi et al. (2006).

The significant increase in the ash content of samples treated with ratio $1: 2 / 2.2$ and $1: 2 / 5.0 \mu \mathrm{l} / \mathrm{g}$ neem - moringa implies that the lower the volume and the concentration of moringa oil in the mixture of oil treatment the more infested the cowpea grains sample. Also the more the endosperm is eaten up, the more the proportion of seed coat in what remains and this component is rich in ash as noted by Gayan et al. (2006).

The highest carbohydrate content $(60.53-61.73 \%)$ of sample treated with ratio $1: 3 / 2.5$ and $5.0 \mu \mathrm{l} / \mathrm{g}$ might be because the bulk of carbohydrate is in the endosperm portion of cowpea grains and these levels of oil preserved the cowpea grains against infestation hence the carbohydrates were not touched. This result is consistent with the report of Ojimelukwe et al. (1999) on the effect of infestation on the nutrient content and physicochemical properties of cowpea.

The mean effect of storage period on the percentage proximate composition of cowpea grains treated with a mixture of neem and moringa seed oils showed that here was no significant difference $(p<0.05)$ in the moisture content of the treated cowpea and the control sample at the end of 90 days of storage but the moisture content decreased at the end of 180 days and later increased at the end of 270 days of storage, this variation could be due to variation in the relative humidity $(\mathrm{RH})$ of the environment within the storage period. The first 90 days was between August - November with Average Relative Humidity $(\mathrm{ARH})$ of 94.34 , then November - February (ARH of 72.88), and March - May (ARH of 80.70). This result is consistent with previous works of llesanmi and
Gungula (2010) who used the mixture of neem and moringa seed oils at various concentrations for the preservation of cowpea. The treated samples gave the most acceptable (10-12\%) safe moisture level for grain storage (Anderson and Alcock, 2013). This is less than the critical (14\%) moisture value for cereals. This may be due to removal of water, with absorption of oils into the grains. The oil might have created moisture barrier for the cowpea grains during storage even when the relative humidity was high. The range of the ash content of $3.18-$ $4.36 \%$ is in line with the work of Owolabi et al. (2012) in which they carried out proximate, antinutrition and mineral composition of five varieties of improved and local cowpea. It is also in agreement with the work of Pandey and Westphal (1989) who reported on chemical composition of cowpea grain. This variation might be due to weevil infestation, wherein the weevil had eaten up the grain remaining mostly the seed coat which contains the chaff that translates to Ash. The ash content is an indicator of the amount of mineral elements in the sample. The result of the fat content of treated and untreated cowpea samples which range from 3.24 to 3.77 is also in agreement with the work of Owolabi et al. (2012).

The result of the percentage fibre content which ranges from 1.17 to $2.80 \%$ recorded is in agreement with the work of Owolabi et al. (2012) and that of Aremuet al. (2006) who carried out a comparative study on the chemical and Amino acid composition of some Nigerian under - utilized legume flours. The $2.39 \%$ fibre observed from sample treated with ratio $1: 2 / 2.5 \mu \mathrm{l} / \mathrm{g}$ at the end of 270 days of storage could be due to weevil infestation which left behind seed coat that resulted in increased fibre because the cowpea endosperm had beeneaten up. This may mean that this concentration $(1: 2 / 2.5 \mu \mathrm{l} / \mathrm{g})$ of the oil was not strong enough to prevent infestation up to a period of 270 days. This finding is consistent with the study carried out by llesanmi and Gungula (2010) which reported a $44 \%$ infestation of cowpea treated with ratio $1: 2$ neem - moringa seed oils at the end of 180 days of storage. This may be responsible for the increment in the percentage protein content of those samples treated with ratio 1:2 mixture of neem and moringa seed oils at the end of 180 to 270 days. The eggs and larvae of Callosobruchusmaculatus might have increased the protein content as these are very high in protein. The protein values recorded for all other treated samples and control from the study were in agreement with the work of Owolabi et al. (2012), Carvalho et al. (2012), and the work of Henshaw (2008), Oyeyinka et al. (2013) and Pandey and Westphal (1989). The drop in percentage carbohydrate content in cowpea grains samples treated with ratio 1:2 mixture of neem - moringa seed oils at the end of 270 days observed in the study could be due to the fact that weevil has eaten up the grains endosperm and the protein content has appreciated leading to drop 
in carbohydrate and may not necessarily be because of the oil.

Interaction between storage period and mixture of neem and moringa seed oils on the percentage proximate composition of store cowpea showed that at 90 days of storage, there was no significant variation in the moisture content of the treated cowpea grains samples and the control (untreated) cowpea grains sample, but at 180 to 270 days of storage, the moisture content of control samples were significantly $(p<0.05)$ higher $(14.20$ and $16.20 \%$ ) than the treated samples which ranged between $6.5-11.5 \%$ ). This is in line with the work of Gyang et al. (2006) who reported that the loss in moisture by the oil treated samples could be due to the removal of water, with the absorption of oil into the grains. They further observed that the increase in the moisture content of the control samples could be due to absorption of atmospheric moisture by increased insect population and increased insect metabolism.

At 90 days of storage, there was no significant $(p<0.05)$ difference in the ash content of control and the treated cowpea grains samples but at the end of 180 to 270 days of storage, significant increment was observed in the ash content of samples treated with ratio 1:2 mixture of neem and moringa seed oils. This component is rich in the seed coat of cowpea grains. Therefore increase in this property may be due to heavy infestation by cowpea bruchids, which consumed the endosperm portion of the grains and left behind the seed coat which is rich in ash component. The same trend observed for protein content of cowpea treated with ratio 1:2 mixture of neem and moringa seed oilsat the end of 180 and 270 days of storage where the protein content increased significantly could be as a result of bruchids eggs and larvae as a result of high infestation, as the insects are very rich in protein. The trend was slightly different with carbohydrate content. At the end of 90 days of storage there were no significant $(p<0.05)$ difference in the carbohydrate content of the treated cowpea and the control, but at the end of 270 days of storage, there were significant reduction in the carbohydrate content of all the cowpea grains except for the sample treated with ratio 1:3 mixture of neem and moringa seed oils. The loss may be due to increase in the protein content of the samples and also due to the bruchid consumption of the endosperm of the cowpea as carbohydrate is concentrated in the endosperm portion of the grains. Carbohydrate content decreased with increase in storage period. This result is in line with Danjumma et al. (2009) who reported the same observations in nutrient composition of maize grains pretreated and stored with plant powders.

Generally, the significant increase in percentage protein, ash and fibre contents and the significant reduction in percentage carbohydrate content of cowpea grains samples treated with ratio 1:2 mixture of neem and moringa seed oils at the end of 270 days as observed from the study, may be due to the degree of infestation with bruchids for samples treated with ratio $1: 2$ neem moringa oil as against cowpea samples treated with 1:3 neem - moringa oil at the end of 180 days of storage as reported by Ilesanmi (2009). This high degree of infestation for samples treated with ratio 1:2 neem moringa oil may be due to low concentration of the moringa oil which translates to lower behenic acid (the active ingredients in moringa oil). This concentration probably is not strong enough to prevent infestation longer than 180 days. The study shows that all those samples treated with ratio $1: 3$ at both levels has no significant difference $(p<0.05)$ in terms of proximate composition when compared with the control. This finding is in line with the findings of Ilesanmi and Gungula (2010) while preserving cowpea grains with mixture of neem and moringa seed oils.

\section{CONCLUSION AND RECOMMENDATION}

The study concluded that treatment of cowpea samples with ratio $1: 3$ mixture of neem and moringa seed oils for storage has no adverse effect on the proximate of the cowpea grains. Ratio 1:3 mixture of neem and moringa seed oils especially ratio $1: 3 / 5.0 \mu \mathrm{l} / \mathrm{g}$ should be used for cowpea grains preservation to get the maximum nutritional benefit from cowpea grains and its products.

\section{REFERENCES}

Anderson JA, Alcock AW (2013).Storage of cereal grains and their products.Fourth edition. Pp.515

AOAC (Association of Official Analytical Chemists) (1990).Official methods of analysis. $15^{\text {th }}$ Edition.Association of Official Analytical Chemists, Washington, DC.

Aremu MO, Olaofe O, Akintayo TE (2006).A comparative study on the chemical and amino acid composition of some Nigerian underutilized legume flours. Pakistan Journal of Nutrition.5(1):34-38.

Asante IK, Adu-Dapaa H, Acheampong AO (2007).Determination of some mineral components of cowpea (Vignaunguiculata (L.)Walp) using instrumental neutron activation analysis. West African $J$. Applied Ecology, Vol. 2, No. 1

Carvalho AFU, Sousa NM, Farias DF, Rocha-Bezerra LCB, Silva RMP, Viana MP, Gouveia ST, Sampaio SS, Sousa MB, Lima GPG, Morais SM, Barros CC, Filho FRF (2012). Nutritional ranking of 30 Brazilian genotypes of cowpeas including determination of antioxidant capacity and vitamins. Journal of Food Composition and Analysis. 26pp.81-88. Available at www.elsevier.com/locate/jfca

Duke JA (1983).Handbook of energy crops.Retrieved from http://www.hort.purdue.edu/newcrop/duke_energy/moringa_oleifera. htmi (Sept 2006)

Egan H, Kirk RS and Sawyer R (1981).Pearson's chemical analysis of foods. Longman Group United Kindom Limited. Pp.137-169.

Henshaw FO (2008). Varietal differences in physical characteristics and proximate composition of cowpea (Vignaungunculata). World Journal of Agricultural Sciences 4(3):302-306.

llesanmi JO, Gungula DT (2010). Preservation of Cowpea [Vignaunguiculata (L.)] walp Grains against Cowpea Bruchids(CallosobruchusMaculatus) using Neem and Moringa Seed Oils. International Journal of Agronomy. Vol. 2010.

llesanmi JOY (2009). Preservation of cowpea (Vignaunguiculata (L.)Walp) against cowpea Bruchids(Callosobruchus maculates) 
124 Afr. J. Food Sci. Technol.

using neem and moringa oils - M. Tech. thesis. Federal University of Technology, Yola.Pp.80-88.

Karunasena PGCS (2001). Investigation of toxic and repellent activity of essential oils of Alpiniacalcarataross and Cymbopogannardus against cowpea weevil. B.Sc. Thesis. University of Kelaniya.SL.

Ojimelukwe PC, Onweluzo JC, Okechukwu E (1999).Effects of infestation on the nutrient content and physiocochemical properties of two cowpea (Vignaunguiculata) varieties. Plant Foods for Human Nutrition, Volume 53, Issue 4, pp 321-332.

Owolabi AO, Ndidi US, James BD, Amune FA (2012). Proximate, antinutrient and mineral composition of five varieties (improved and local) of cowpea, Vignaunguiculata, commonly consumes in Samaru community, Zaria - Nigeria. Asia J. Food Sci. and Technology 4(2): 70-72.
Oyeyinka SA Oyeyinka AT, Karim OR, Kayode RMO, Balogun MA, Balogun OA (2013). Quality attributes of weevils (Callosobruchusmaculatus) infested cowpea (Vignaunguiculata) products. Nigerian J. Agric. Food and Environ. 9(3):16-22.

Pandey RK, WestphalE (1989).Vignaunguiculata(L.)Walp. [Internet] Record from Proseabase.van derMaesen LJG, Somaatmadja S (Editors). PROSEA (PlantResources of South East Asia) Foundation, Bogor, Indonesia.http://www.proseanet.org. Accessed from Internet: 21 Aug 2011 